\title{
Emotion Distress and Self-Care Behavior in Type II Diabetes Mellitus Patients in Matsum, Medan, North Sumatera
}

\author{
Susy Hariaty Situmorang, Namora Lumongga Lubis, Kintoko Rochadi
}

Faculty of Public Health, Universitas Sumatera Utara

\begin{abstract}
Background: Diabetes mellitus (DM) is currently one of the major health problems in the world because it has an impact on declining productivity and quality of human resources. This disease also causes sufferers to experience a state of disability, loss of productivity, and become a burden for individuals, families and communities that can cause emotional distress in people with diabetes mellitus. The purpose of this study was to determine the effect of emotional distress on self-care behavior of people with type 2 diabetes mellitus at the Matsum Health Center.

Subjects and Method: This study used a cross sectional design conducted at Matsum Health Center in Medan. The number of samples was 49 people and taken with non-probability sampling technique by quota sampling. The dependent variable was self-care behavior. The independent variable was emotional distress. Data were collected by questionnaires and analyzed using Chi square test.

Results: Low emotional distress increases self-care behavior in patients with type 2 diabetes mellitus $(\mathrm{OR}=11.33$; 95\% CI with $\mathrm{p}=0.004)$.

Conclusion: Low emotional distress increases self-care behavior in patients with type 2 diabetes mellitus.
\end{abstract}

Keywords: Emotional distress, self-care behavior, diabetes.

\section{Correspondence:}

Susy Hariaty Situmorang. Masters Program in Public Health, Universitas Sebelas Maret. Email: susysitumorang88@gmail.com. Mobile: 081220230986.

\section{BACKGROUND}

$\overline{\mathrm{DM}}$ and its complications are a big problem especially in developing countries including Indonesia. DM and its complications also directly affect human productivity. Global data shows that there are 415 million DM sufferers worldwide ( 1 in 11 suffer from $\mathrm{DM}$ ) and it is estimated that there will be 642 million DM sufferers by 2040 (IDF, 2016). According to the International Diabetes Federation (IDF) Report in 2015, Indonesia is in the top 10 with the highest number of DM sufferers in the world. In 2015, it was ranked 7 th with an average number of sufferers of 10 million people (8.7-10.9 million). It is estimated to be ranked 6th in 2040 with an average number of sufferers of 16.2 million people (14.3 -17.7 million).

The prevalence of DM in Indonesia in 2015 was $8.7 \%$. It increased four times compared to the Riskesdas (Basic Health Research) 2013 data which was only $2.1 \%$ (IDF, 2016).

DM in Medan is more common in women, which is 1295 cases. This requires attention and follow-up for prevention and treatment because an increase in the prevalence of type 2 diabetes will be followed by an increase in other disease complications. The problem of DM and its effects has received worldwide attention, including the Government of Indonesia. The Ministry of Health has also developed several programs to prevent and overcome 
Journal of Health Promotion and Behavior (2019), 4(2): 153-158

https://doi.org/10.26911/thejhpb.2019.04.02.08

DM such as: prevention and control of risk factors; early discovery and case management; epidemiological surveillance; and communication, information and education (IEC) about DM (Ministry of Health, 2014).

The main risk factors for type 2 diabetes are obesity and lack of physical activity. The low level of physical activity will affect the occurrence of type 2 diabetes. Based on Riskesdas in 2007, physical activity in the age group $>10$ years was $48.2 \%$ and the prevalence had decreased to $26.1 \%$ Riskesdas' resultsin the 2013. Several epidemiological studies were increasing also showed an association between physical activity and the incidence of type 2 diabetes. The main key to type 2 diabetes therapy is through diet and lifestyle adjustments to prevent and overcome obesity, pharmacological and nonpharmacological strategies to reduce glucose levels, and treatment to reduce cardiovascular risk especially lowering blood pressure and cholesterol (Bilous and Donelly, 2014).

At the psychological level, stress in the form of rejection, worry, feelings of helplessness, and bad stigma about stressful is also able to produce negative or nonconstructive feelings towards self. Intellectually, it can affect the perception and ability of individuals to solve problems and take care of themselves. Treatment provided is given in the form of a program that is quite strict and requires good self-care skills and is emphasized in an effort to control blood sugar levels. It is generally known that the level of adherence in the treatment of chronic diseases and lifestyle changes is a difficult problem and only reaches around $50 \%$.

The results showed that adherence in one treatment was not related to adherence to other treatments. For example, adherence to medical treatment is greater than adherence to lifestyle changes (Alam et al., 2016). Forms of self-care activities that constitute adherence to lifestyle changes include nutrition management, physical activity, and monitoring of independent blood glucose levels (Naderimagham et al, 2012).

From the preliminary survey results in the Matsum Health Center 7 out of 10 DM patients do not do sports or physical activities due to laziness, busyness and the presence of other diseases such as gout. The management of type 2 DM so far in health center only moves on physical health, namely preventing acute and chronic complications, while psychological and social aspects have not been reached. In addition, from the interviews with $15 \mathrm{DM}$ patients 11 of them said that they became irritable and easily offendedbecause they felt anxious and useless to their families.So, they were lazy to seek treatment and felt life had no meaning and always became a parasite for their families.

The purpose of this study was to determine whether there was an effect of emotional distress on the self-care behavior of people with Type 2 Diabetes Mellitus in the Matsum Health Center or not.

\section{SUBJECT AND METHOD}

\section{Design of the Study}

This study was an analytic study using cross sectional design.

\section{Population and sample}

The population in this study were all patients with type $2 \mathrm{DM}$ who underwent outpatient treatment at Matsum Health Center and the samples were 49 people.

\section{Study Variables}

The dependent variable of this study was self-care behavior. The independent variable was emotional distress.

\section{Operational Definition of Variables}

The operational definition of the dependent variable of self-care behavior was the acti- 
vity carried out independently by people with Type 2 diabetes which included diet / dietary management, physical activity, monitoring of blood glucose levels, drug consumption, and foot care carried out in the last 7 days. For the independent variable, emotional distress was the self-statement about the burden experienced related to the illness.

\section{Study Instrument}

The instrument of the study used was the Diabetes Distress Scale (DDS) questionnaire and the self-care behavior question- naire through the Summary of Diabetes Self Care Activities (SDSCA).

\section{Data Analysis}

The data were analyzed by Spearman rank.

\section{RESULTS}

\section{Univariate analysis}

Table 1 showed sample characteristics. Table 1 showed that sample mostly were at age $\geq 46$ years old $(83.7 \%)$, female $(75.51 \%)$, did not consume diabetic drugs (69.39\%), and duration of illness $\geq 5$ years (95.52\%).

Table 1. Sample characteristics of type 2 diabetes mellitus patients in Matsum Health Center, Medan

\begin{tabular}{lcc}
\hline Category & n & \% \\
\hline Age & & \\
$<46$ years old & 8 & 16.3 \\
$\geq 46$ years old & 41 & 83.7 \\
Gender & & \\
Male & 12 & 24.49 \\
Female & 37 & 75.51 \\
Drug Consumption & & \\
Doctor's prescription & 8 & 16.33 \\
Herbal medicine & 7 & 14.29 \\
Do not consume drugs & 34 & 69.39 \\
Duration of illness & & 4.08 \\
< 5 years & 2 & 95.92 \\
$\geq 5$ years & 47 & \\
\hline
\end{tabular}

\section{Bivariate analysis}

Table 2 showed bivariate analysis. Table 2 showed that 34 samples (91.9\%) with low emotional distress had good self-care

Table 2. The effect of emotional distress of self-care behavior on diabetes mellitus patients

\begin{tabular}{lcccccccc}
\hline \multirow{2}{*}{$\begin{array}{c}\text { Emotional } \\
\text { Distress }\end{array}$} & \multicolumn{3}{c}{ Self-care behavior } & & \multirow{2}{*}{ OR } & \multirow{2}{*}{ 95\% CI } & p \\
\cline { 2 - 5 } & $\mathbf{n}$ & $\mathbf{\%}$ & $\mathbf{n}$ & $\mathbf{\%}$ & & & \\
\hline Low & 34 & 91.94 & 3 & 8.12 & & 11.33 & 2.21 to 58.15 & 0.004 \\
High & 6 & 50 & 6 & 50 & & & \\
\hline
\end{tabular}

\section{DISCUSSION}

Diabetes distress is a unique emotional problem that is directly related to the burden and worries of living with a chronic illness. This condition is indicated by 'worry, frustration, and maybe a little behavior. Low emotional distress increased good self-care behavior $(\mathrm{OR}=11.33$; $\mathrm{p}=$ 0.004). fatigue. These emotions can be related to, for example, to concerns about appropriate treatment or to communicate effectively with health care providers (Gebel, 2013). The results of this study indicate that low emotional distress increases self-care 
Journal of Health Promotion and Behavior (2019), 4(2): 153-158

https://doi.org/10.26911/thejhpb.2019.04.02.08

behavior in patients with type $2 \mathrm{DM}$ in Matsum Health Center, Medan.

Stress has effects on self-care behavior or diabetes management that are not fully understood by health services. The impact of stress is a confounding variable that can affect a person's ability to manage diabetes, so that it has a bad impact on metabolic control and psychological wellbeing. Rubin and Peyrot (2001) in Wardian (2014) explained that psychosocial issues have effects on diabetes self-management and self-care that are not fully understood by health workers. There is a significant association between emotional aspects with the low level of independence of someone to do self-care activities. Psychosocial barriers to diabetes distress and the low level of independence of a person in conducting self-care activities are caused by several factors such as self-efficacy. Wingert et al. (2015) suggested that high self-efficacy increases one's compliance with carrying out self-care activities.

According to individual researchers who have diabetes mellitus in controlling the state of hyperglycemia requires changes in lifestyle and diet.However,for diabetics who are still in the early stages, this is very difficult to do because over the past decades their habits must be changed to a healthy lifestyle. For diabetic patients who undergo a brief change in healthy lifestyle is not easy and makes individuals feel stressed and even depressed (Smeltzer \& Bare, 2006). Conditions in people who suffer from it are feeling worried, depressed, and feeling burdened with their illnesses, so they need support from someone.

This support can be obtained from the closest people such as family, husband, wife, or children. With this support, stress is expected to be reduced so that the treatment of diabetic patients becomes orderly and disciplined. This is also supported by a study conducted by Irfan \& Wibowo (2015), which stated that one solution to reduce the stress level experienced by diabetics is to seek support from the family. Family support is expected to make stress turn into something positive.

\section{AUTHOR CONTRIBUTIONS}

$\overline{\text { Susy Hariaty Situmorang collected data and }}$ analyzed data. Namora Lumongga Lubis examined the conceptual framework and suggested a methodology. Kintoko Rochadi interpreted the results of data analysis.

\section{ACKNOWLEDGEMENT}

The author would like to thank Matsum Health Center in Medan and those who had participated in this study.

\section{FUNDING AND SPONSORSHIP}

This study used the authors' personal funds.

\section{CONFLICT OF INTEREST}

There is no conflict of interest.

\section{REFERENCE}

Potter A, Perry AG (2006). Buku ajar fundamental keperawatan: Konsep, proses, dan praktik, edisi 4, Volume. 2. Jakarta: EGC.

ADA (1997). About Blood Pressure. American Heart Association.

ADA (2015). Standar of medical care in diabetes-2015. Diabetes Care,38.

Alam DS, Talukder SH, Muhammad AHC, Ali TS, Ahmed S, Pervin S, Niessen LW (2016). Overweight and abdominal obesity as determinants of undiagnosed diabetes and pre-diabetes in bangladesh. BMC Obesity, 3. doi: http://dx.doi.org/10.1186/s40608016-0099-z 
Alfian R (2015). Layanan pesan singkat pengingat untuk meningkatkan kepatuhan minum obat dan kontrol glikemik pasien diabetes melitus di RSUD Dr. H. Moch., Ansari Saleh Banjarmasin, Jurnal Media Farmasi, 129138.

Arief M (2008). Pengantar metodologi penelitian untuk ilmu kesehatan. Surakarta: LPP UNS Press.

Asdie AI (2010). Patogenesis dan terapi diabetes mellitus tipe 2. Yogyakarta: MEDIKA Fakultas Kedokteran Universitas Gadjah Mada.

Awad N, Langi YA, Pandelaki K (2013). Gambaran faktor resiko pasien diabetes melitus tipe II di Poliklinik Endokrin Bagian/ SMF FK-UNSRAT RSU Prof. Dr. R.D Kandou Manado Periode Mei 2011-Oktober 2011, Jurnal e-Biomedik. 1(1): 45 - 49. Doi: https://doi.org/10.35790/ebm.1.1.201 3.1160 .

Balitbangkes Depkes RI (2007). Riset kesehatan dasar Indonesia Tahun 2007. Badan Penelitian dan Pengembangan Kesehatan Departemen Kesehatan Republik Indonesia. Jakarta.

Bandura A (1997). Self-Efficacy: The Exercise of Control. New York: W.H. Freeman and Company.

Brunner S (2005). Keperawatan medikal bedah (Edisi Delapan). Jakarta: EGC

Bilous R, Donelly R (2014). Buku Pegangan Diabetes Edisi ke 4. Jakarta: Bumi Medika.

Smeltzer SC, Bare BG (2008). Buku Ajar Keperawatan Medikal Bedah. Vol. 2. Ed.10. Jakarta: EGC

Suiraoka IP (2012). Penyakit degeratif mengenal mencegah dan mengurangi faktor risiko. Yogyakarta: Nuha Medika

Susanti ML, Sulistyarini T (2013). Dukungan keluarga meningkatkan pasien diabetes melitus di ruang rawat inap RS Baptis Kediri. Jurnal STIKES, 6(1). Supriyadi D, Kusyati E, Sulistyawati E (2013). Pengaruh pendidikan kesehatan dengan metode demonstrasi terhadap kemampuan merawat kaki pada penderita diabetes mellitus. Jurnal Managemen Keperawatan, 1(1): 39-47.

Taylor SE (2003). Health Psychology. New York: McGraw Hill.

Trisnawati SK, Setyorogo S (2013). Faktor risiko kejadian diabetes melitus tipe II di Puskesmas Kecamatan Cengkareng Jakarta Barat Tahun 2012. Jurnal Ilmiah Kesehatan, 5(1): 6-11.

Yusuf M (2014). Metode penelitian kuantitatif, kualitatif \& penelitian gabungan. Jakarta: Prenada Media

Yusra A (2011). Hubungan antara dukungan keluarga dengan kualitas hidup pasien diabetes melitus tipe 2 di poliklinik penyakit dalam Rumah Sakit Umum Pusat Fatmawati Jakarta. Tesis. FIK UI. Depok

World Health Organization (1998). Health promotion glossary. Jakarta.

World Health Organization (2003). Adherence to long term therapies, evidence for action.

World Health Organization (2006). Preventing chronic disease 2 vital investment. Public Health of Canada.

World Health Organization (2009). Global health risks: Mortality and burden of disease attributable to selected major risks.

Warsito H (2004). Hubungan antara efikasi diri dengan penyesuaian akademik dan prestasi akademik. Jurnal Psikologi, 14(2): 92-109.

Zahtamal, Chandra F, Suyanto, Restuastuti $\mathrm{T}$ (2007). Faktor-faktor risiko pasien diabetes melitus di RS Arifin Achmad 
Journal of Health Promotion and Behavior (2019), 4(2): 153-158

https://doi.org/10.26911/thejhpb.2019.04.02.08

Riau. Berita Kesehatan Masyarakat. 23(23): 142-147.

Zainuddin M, Utomo W, Herlina (2015).

Hubungan Stress dengan Kualitas
Hidup Penderita Diabetes Melitus

Tipe 2. JOM. 2(1). 